Celebes Abdimas: Jurnal Pengabdian Kepada Masyarakat

http://journal.lldikti9.id/CER/index

Vol 2, No, 2, Oktober 2020, pp 53-57

p-ISSN:2656-7938 dan e-ISSN: 2657-1870

DOI: https://doi.org/10.37541/celebesabdimas.v2i2.451

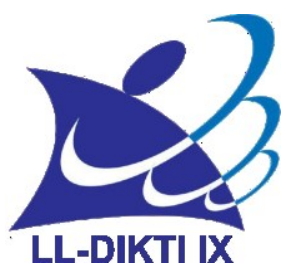

\title{
Edukasi Online Pelaksanaan Aktifitas Fisik Pada Pasien Diabetes Melitus Di Masa Pandemi Covid-19
}

\author{
Fitria Alisa ${ }^{1}$, Weny Amelia ${ }^{2}$, Lenni Sastra ${ }^{3}$, Lola Despitasari ${ }^{4}$ \\ 1,2,3,4 Keperawatan, STIKes Mercubaktijaya Padang, Indonesia \\ Email: fitriaalisa1985@gmail.com;
}

\section{Artikel info}

Article history:

Received: 03-September-2020 Revised: 10 -September-2020

Accepted: 11- Oktober-2020

Publish: 28-Oktober-2020
Abstract. Diabetes mellitus (DM) is a chronic metabolic disorder characterized by high blood sugar levels as a result of insufficient insulin function caused by disruption of insulin products by beta Langerhans cells or the body's cells are less responsive to insulin. Covid-19 attacks almost all ages, especially people who have a history of chronic disease (co-morbid) have a risk of getting it more frequently and with worse complications from this disease. One of the chronic disease history is DM. Physical exercise or physical activity is one of the pillars in the management of DM which functions to improve insulin sensitivity and also to maintain body fitness during the COVID-19 Pandemic. The form of community service activities carried out in the DM patient group includes education to patients and families about online education for DM sufferers during the COVID-19 pandemic. The results of community service activities obtained an increase in knowledge about the implementation of physical activity for DM patients during the COVID-19 pandemic.

Abstrak. Diabetes Melitus (DM) merupakan gangguan metabolisme kronis yang ditandai dengan tingginya kadar gula darah sebagai akibat insufisiensi fungsi insulin yang disebabkan oleh gangguan produk insulin oleh sel beta langerhans atau kurang responsifnya sel tubuh terhadap insulin. Covid-19 menyerang hampir seluruh kalangan usia terutama orang yang mempunyai riwayat penyakit kronis (ko-morbid) memiliki risiko untuk terkena lebih sering dan dengan komplikasi yang lebih buruk dari penyakit ini. Riwayat penyakit kronis salah satunya adalah DM. Latihan fisik atau aktifitas fisik merupakan salah satu pilar dalam pengelolaan DM yang berfungsi untuk memperbaiki sensitivitas insulin dan juga untuk menjaga kebugaran tubuh di masa Pandemi COVID-19. Bentuk kegiatan pengabdian kepada masyarakat yang dilakukan pada kelompok pasien DM meliputi edukasi pada pasien dan keluarga tentang edukasi online bagi penderita DM di masa pandemi COVID-19. Hasil dari kegiatan pengabdian kepada masyarakat didapatkan peningkatan pengetahuan tentang pelaksanaan aktifitas fisik pasien DM di masa pandemi COVID-19. 
54| Celebes Abdimas: Jurnal Pengabdian Kepada Masyarakat

\author{
Keywords: \\ Physical Activity; \\ Diabetes mellitus; \\ Online Education; \\ The Covid-19 \\ pandemic
}

Coresponden author:

Weny Amelia

Keperawatan, STIKes Mercubaktijaya Padang

Email: wenyamelia.wa@gmail.com

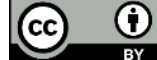

artikel dengan akses terbuka dibawah lisensi CC BY -4.0

\section{PENDAHULUAN}

Pandemi virus korona yang disebabkan oleh SARS-CoV-2 (penyakitnya disebut dengan COVID-19) telah menginfeksi lebih dari 1 juta orang dari berbagai kalangan diseluruh dunia. Data di Indonesia saat ini juga memperlihatkan kecenderungan yang terus meningkat. Penyakit ini relatif baru, memiliki perjalanan penyakit yang cepat dan sangat mudah menular namun sebagian besar sifat-sifatnya masih belum dipahami. Covid-19 ini bisa menyerang hampir seluruh kalangan usia, namun demikian data yang ada saat ini menunjukkan bahwa kelompok usia lanjut dan orang yang mempunyai riwayat penyakit kronis (ko-morbid) memiliki risiko untuk terkena lebih sering dan dengan komplikasi yang lebih buruk dari penyakit ini. Riwayat penyakit kronis yang dimaksud antara lain adalah hipertensi, diabetes melitus, penyakit kardiovaskuler, dan penyakit paru kronis. Khusus untuk mereka dengan diabetes, merupakan komorbiditas kedua tersering ditemukan, sekitar 8\% kasus, setelah hipertensi (Yang et al., 2020) dan dengan angka kematian tiga kali lipat dibandingkan penderita secara umum $(7.3 \%$ berbanding 2.3\%) (Wu \& McGoogan, 2020).

Diabetes Melitus (DM) merupakan salah satu faktor risiko meningkatnya keparahan infeksi COVID-19. Diabetesi yang berusia lebih tua ( $>60$ tahun), kadar gula darah tidak terkontrol, dan adanya komplikasi diabetes dikaitkan dengan prognosis COVID-19 yang buruk. Di China, persentase tingkat kematian diabetesi yang terdiagnosa COVID-19 adalah 7.3\%. Di Italia, kematian pada pasien Covid-19 ternyata 36\% berkaitan dengan diabetes (Onder et al., 2020). Laporan dari Philippine - Department of Health (DOH) menunjukkan bahwa diabetes dan hipertensi merupakan komorbid terbanyak pada kematian pasien COVID-19 di Filipina (PERKENI, 2020).

DM merupakan gangguan metabolisme kronis yang ditandai dengan tingginya kadar gula darah sebagai akibat insufisiensi fungsi insulin yang disebabkan oleh gangguan produk insulin oleh sel beta langerhans atau kurang responsifnya sel tubuh terhadap insulin (Masriadi, 2016). DM terdiri dari 3 macam yaitu DM tipe 1, DM tipe 2 dan DM gestasional, dimana diantaranya lebih dari $90 \%$ populasi DM yang dialami oleh masyarakat Indonesia adalah DM tipe 2 sedangkan sisanya 5\%-10 \% adalah DM tipe 1 dan DM gestasional (Tandra 2017).

DM tipe 2 atau sering disebut dengan Non Insulin Dependen Diabetes Mellitus (NIDDM) merupakan gangguan yang terjadi pada onset dewasa berupa penurunan sensitivitas insulin terhadap kadar glukosa darah (Black \& Hawks 2014). Keluhan yang sering ditemukan pada DM tipe 2 yaitu poliuria, polidipsia, luka yang lama sembuh, pandangan kabur, kesemutan, bisul, rasa lemah. Jika kadar glukosa sangat tinggi akan berdampak pada kerusakan pada pembuluh darah di seluruh tubuh (Wijaya, 2013).

Berdasarkan International Diabetes Federation (IDF, 2019) jumlah kasus pasien DM di dunia mengalami peningkatan setiap tahunnya. Pada tahun 2011 (366 juta), 2013 (382 juta), 2015 (415 juta), 2017 (425 juta), 2019 (463 juta) dengan tingkat diabetes 9,0\% pada wanita dan 9,6\% pada pria. Sedangkan diperkirakan tahun 2030 (578 juta), dan 2045 diperkirakan angka kejadian akan terus meningkat menjadi 700 juta jiwa yang akan terdiagnosa DM (Yuen, Saeedi, and Riaz, 2019).

Indonesia menempati peringkat ke -7 terbanyak tahun 2019 untuk penderita DM setelah China, India, USA, Brazir, Mexico yaitu 10,7 juta. Angka kejadian DM diproyeksi dan diperkirakan akan meningkat mencapai 16,6 tahun 2045 (IDF, 2019). Jumlah pasien DM di 
Indonesia mengalami peningkatan dari 6,9\% tahun 2013 menjadi 8,5\% pada tahun 2018 . Sumatera Barat berada di urutan 22 dari 35 provinsi dengan pravelensi pasien DM 1,2\% dan mengalami peningkatan 2,2\% tahun 2018 (Riskesdas, 2018).

Gula darah yang tidak terkontrol merupakan predisposisi diabetisi untuk menderita infeksi yang parah. Untuk menghindari hal tersebut, kontrol glikemik yang ketat harus diterapkan setiap saat. Sangat disarankan untuk memiliki alat pemeriksa glukosa darah mandiri sehingga pasien DM dapat melakukan pengecekan glukosa darah dirumah. Individu dengan DM disarankan untuk mengonsumsi asupan diet yang tepat dan latihan fisik di rumah. Hal ini dapat meningkatkan kontrol glikemik dan mengurangi risiko infeksi.

Latihan fisik atau aktifitas fisik merupakan salah satu pilar dalam pengelolaan DM yang berfungsi untuk memperbaiki sensitivitas insulin dan juga untuk menjaga kebugaran tubuh. Latihan fisik bisa membantu memasukan glukosa kedalam sel tanpa membutuhkan insulin, selain itu latihan fisik juga bisa untuk menurunkan berat badan diabetisi yang obesitas serta mencegah laju progresivitas gangguan toleransi glukosa menjadi DM. Pada saat tubuh bergerak, akan terjadi peningkatan kebutuhan bahan bakar tubuh oleh otot yang aktif, juga terjadi reaksi tubuh yang kompleks meliputi fungsi sirkulasi metabolisme, pelepasan dan pengaturan hormonal dan susunan saraf otonom. Pada keadaan istirahat, metabolisme otot hanya sedikit sekali memakai glukosa sebagai sumber bahan bakar, sedangkan saat berolahraga, glukosa dan lemak akan dijadikan sebagai bahan bakar utama. Diharapkan dengan dijadikannya glukosa sebagai bahan bakar utama, kadar glukosa darah akan menurun (Azitha et al., 2018).

Berdasarkan hasil survey awal yang dilakukan pada 14 orang pasien DM, didapatkan bahwa 11 orang pasien telah melakukan aktifitas fisik, tetapi aktifitas fisik dilakukan seperti kondisi biasa saat sebelum terjadi pandemi COVID-19 yaitu jalan kaki diluar rumah dan bertani. Hasil survey awal juga menunjukkan 11 orang pasien memiliki kadar gula darah yang tinggi berdasarkan hasil kadar gula darah yang diperiksa pasien saat berkunjung ke pelayanan kesehatan. 14 orang pasien yang dilakukan survey awal tersebut juga belum pernah mendapatkan edukasi tentang aktifitas fisik penderita DM saat pandemi COVID-19.

Upaya pemberdayaan pasien DM dan keluarga dalam melakukan aktifitas fisik perlu dilakukan untuk mengontrol kadar gula darah pasien dan secara khusus juga untuk meningkatkan imunitas pasien di saat pandemi COVID-19 ini. Berdasarkan uraian di atas, salah satu upaya yang dapat dilakukan perawat adalah dengan memberikan edukasi online kepada pasien dan keluarga tentang penatalaksanaan aktifitas fisik pada pasien DM di masa pandemi COVID-19.

\section{METODE}

Metode pelaksanaan pengabdian kepada masyarakat ini yaitu dengan melakukan edukasi kesehatan secara online pada pasien DM dan keluarganya. Edukasi kesehatan dilakukan secara online malalui media zoom meeting. Jumlah peserta yang direncanakan hadir pada saat edukasi adalah 20 orang. Pasien DM didampingi oleh keluarga pada saat edukasi. Evaluasi dilakukan menggunakan kuesioner tentang penatalaksanaan aktifitas fisik yang terdiri dari 10 pertanyaan dengan jawaban berupa pilihan ganda. Evaluasi dilakukan untuk menilai pengetahuan peserta sebelum dan sesudah diberikan edukasi online. Metode pelaksanaan untuk kegiatan pengabdian kepada masyarakat tentang edukasi online pelaksanaan aktifitas fisik pada pasien DM di masa pandemi COVID-19 terdapat dalam tabel berikut. 
56 | Celebes Abdimas: Jurnal Pengabdian Kepada Masyarakat

Tabel 1. Metode Pelaksanaan

\begin{tabular}{|c|c|c|}
\hline & Rencana Kegiatan & Partisipasi Mitra \\
\hline 1 & Sosialisasi rencana kegiatan & $\begin{array}{l}\text { a. Membantu persiapan sarana edukasi online } \\
\text { b. Hadir pada saat sosialisasi kegiatan } \\
\text { c. Membuat komitmen bersama untuk bekerja } \\
\text { sama dalam kegiatan }\end{array}$ \\
\hline 2 & $\begin{array}{l}\text { Edukasi online pada pasien dan } \\
\text { keluarga tentang pelaksanaan } \\
\text { aktifitas fisik bagi penderita DM }\end{array}$ & $\begin{array}{l}\text { a. Membantu persiapan sarana dan media } \\
\text { edukasi online } \\
\text { b. Hadir pada saat edukasi } \\
\text { c. Berperan aktif pada saat edukasi }\end{array}$ \\
\hline
\end{tabular}

\section{HASIL DAN PEMBAHASAN}

Pelaksanaan kegiatan pengabdian kepada masyarakat berupa edukasi online pelaksanaan aktifitas fisik pada pasien DM di masa pandemi COVID-19 dilaksanakan pada hari Senin,1 Juni 2020. Jumlah peserta yang hadir pada saat edukasi adalah 14 orang. Metode yang dilakukan adalah memberikan edukasi secara online melalui media zoom meeting. Dalam kegiatan ini juga dilakukan sesi tanya jawab. Hasil dari kegiatan didapatkan terdapat peningkatan pengetahuan pasien tentang pelaksanaan aktifitas fisik pasien DM. Berikut gambaran hasil pelaksanaan kegiatan :

Tabel 2. Distribusi Frekuensi Tingkat Pengetahuan Peserta PKM tentang Pelaksanaan Aktifitas Fisik pada Pasien DM $(\mathrm{n}=14)$

\begin{tabular}{clcccc}
\hline \multirow{2}{*}{ No } & \multirow{2}{*}{ Pengetahuan } & \multicolumn{2}{c}{ Pretest } & \multicolumn{2}{c}{ Postest } \\
\cline { 3 - 6 } & & n & \% & n & \% \\
\hline 1 & Baik & 5 & 35,7 & 13 & 92,9 \\
2 & Kurang baik & 9 & 64,3 & 1 & 7,1 \\
\hline \multicolumn{2}{r}{ Total } & 14 & 100 & 14 & 100 \\
\hline
\end{tabular}

Berdasarkan tabel 2 di atas diketahui bahwa sebelum diberikan edukasi, sebagian besar $(64,3 \%)$ pasien DM memiliki pengetahuan yang kurang baik tentang pelaksanaan aktifitas pasien DM. Setelah diberikan edukasi terjadi peningkatan pengetahuan peserta pengabmas yaitu sebesar 92,9\% sudah memiliki pengetahuan yang baik tentang pelaksanaan aktifitas pasien DM.

Pemberian edukasi online dapat meningkatkan pengetahuan individu atau kelompok. Hal ini sesuai dengan penelitian yang dilakukan oleh (Lisiswanti \& Cordita, 2016) tentang pengaruh pendidikan kesehatan terhadap pengetahuan, perilaku dan gula darah pada pasien diabetes mellitus tipe 2. Berdasarkan hasil penelitian ini pendidikan kesehatan atau edukasi merupakan salah satu metode yang dapat dilakukan untuk meningkatkan pengetahuan dan perilaku pasien DM tentang aktifitas fisik. Dokumentasi kegiatan pengabdian masyarakat yang dilakukan dapat dilihat pada gambar berikut :
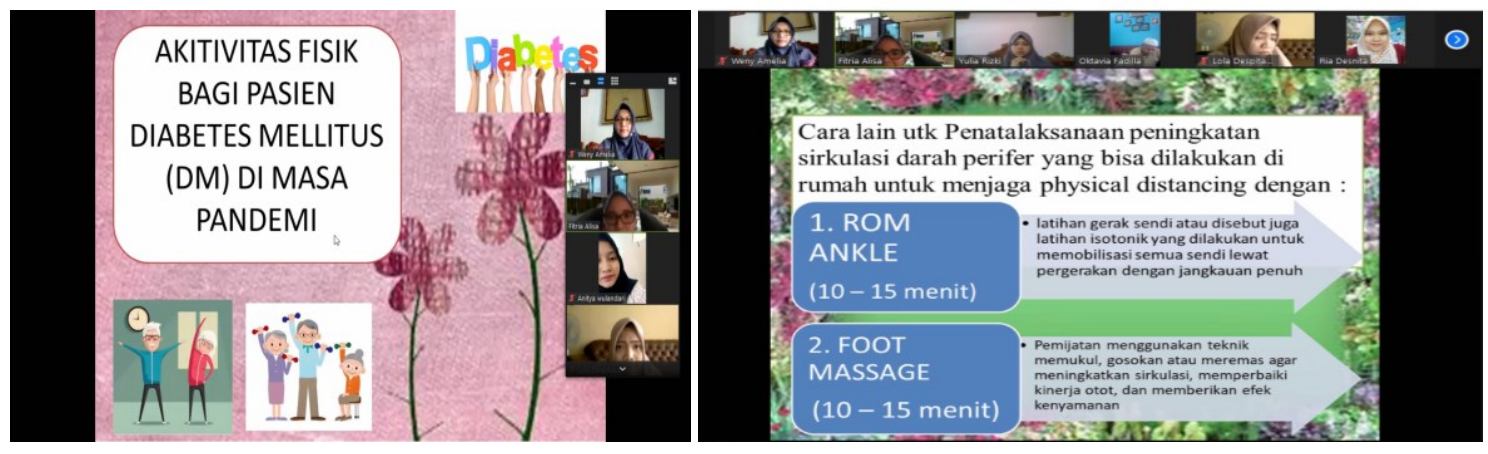

Gambar 1. Penyampaian Materi tentang Pelaksanaan Aktifitas Fisik Pasien DM 


\section{SIMPULAN DAN SARAN}

Kegiatan pengabdian kepada masyarakat berupa edukasi online pelaksanaan aktifitas fisik pada pasien DM di masa pandemi COVID-19 dapat meningkatkan pengetahuan pasien DM yang menjadi peserta dalam kegiatan ini. Peran perawat dalam pengelolaan Diabetes Melitus selain berkontribusi langsung sebagai pemberi asuhan keperawatan diharapkan juga melakukan pengelolaan DM di masyarakat dengan berberan sebagai edukator yang dapat mengedukasi pasien DM khususnya dalam pelaksanaan aktifitas fisik.

\section{DAFTAR RUJUKAN}

Azitha, M., Aprilia, D., \& Ilhami, Y. R. (2018). Hubungan Aktivitas Fisik dengan Kadar Glukosa Darah Puasa pada Pasien Diabetes Melitus yang Datang ke Poli Klinik Penyakit Dalam Rumah Sakit M. Djamil Padang. Jurnal Kesehatan Andalas, 7(3), 400. https://doi.org/10.25077/jka.v7i3.893

Black, J. (2014). KEPERAWATAN MEDIKAL BEDAH (A. Susila (Ed.); 8th ed.). Pt Salemba Emban Patria.

Hasil-riskesdas-2018_1274. (n.d.).

Lisiswanti, R., \& Cordita, R. N. (2016). Aktivitas fisik dalam Menurunkan Kadar Glukosa Darah pada Diabetes Melitus Tipe 2. Majority, 5(3), 140-144.

Masriadi. (2016). Epidemiologi Penyakit Tidak Menular. TIM.

Onder, G., Rezza, G., \& Brusaferro, S. (2020). Case-Fatality Rate and Characteristics of Patients Dying in Relation to COVID-19 in Italy. JAMA - Journal of the American Medical Association, 323(18), 1775-1776. https://doi.org/10.1001/jama.2020.4683

PERKENI. (2020). Pernyataan Resmi dan Rekomendasi Penanganan Diabetes Mellitus di era Pandemi COVID-19. The Indonesian Society of Endocrinology, 1-5.

Tandra, H. (2017). SEGALA SESUATU YANG HARUS ANDA KETAHUI TENTANG DIABETES.

Wijaya, A. (2013). KMB 2 Keperawatan Medikal Bedah (Keperawatan Dewasa).

Wu, Z., \& McGoogan, J. M. (2020). Characteristics of and Important Lessons from the Coronavirus Disease 2019 (COVID-19) Outbreak in China: Summary of a Report of 72314 Cases from the Chinese Center for Disease Control and Prevention. JAMA - Journal of the American Medical Association, 323(13), 1239-1242. https://doi.org/10.1001/jama.2020.2648

Yang, J., Zheng, Y., Gou, X., Pu, K., Chen, Z., Guo, Q., Ji, R., Wang, H., Wang, Y., \& Zhou, Y. (2020). Prevalence of comorbidities and its effects in coronavirus disease 2019 patients: A systematic review and meta-analysis. International Journal of Infectious Diseases, 94, 91-95. https://doi.org/10.1016/j.ijid.2020.03.017

Yuen, L., Saeedi, P., Riaz, M., Karuranga, S., Divakar, H., Levitt, N., Yang, X., \& Simmons, D. (2019). IDF Diabetes Atlas: Projections of the prevalence of hyperglycaemia in pregnancy in 2019 and beyond: Results from the International Diabetes Federation Diabetes Atlas, 9th edition. Diabetes Research and Clinical Practice, 157, 107841. https://doi.org/10.1016/j.diabres.2019.107841 